\title{
REVEALING THE BEHAVIOR INTENTION OF TECH- SAVVY GENERATION Z TO USE ELECTRONIC WALLET USAGE: A THEORY OF PLANNED BEHAVIOR BASED MEASUREMENT
}

\author{
Satria Fadil Persada* \\ Institut Teknologi Sepuluh Nopember \\ Irfandy Dalimunte \\ Institut Teknologi Sepuluh Nopember \\ Reny Nadlifatin \\ Institut Teknologi Sepuluh Nopember \\ Bobby Ardiansyah Miraja \\ Institut Teknologi Sepuluh Nopember \\ Anak Agung Ngurah Perwira Redi \\ Bina Nusantara University \\ Yogi Tri Prasetyo \\ Mapua University \\ Jacky Chin \\ Mercu Buana University \\ Shu-Chiang Lin \\ Texas Health and Science University
}

- Corresponding author: Department of Business Management, Institut Teknologi Sepuluh Nopember, Campus ITS, Indonesia; 


\begin{abstract}
Tech-savvy Generation $\mathrm{Z}$ will dominate the global population. Thus, in order to stay competitive, it is essential for a business that targets this demographic to understand this generation's characteristics. The present research measured the behavioral nature of Generation $\mathrm{Z}$ in using the electronic wallet (e-wallet). Specifically, the present research highlighted online and in-store transactions. The measurement in this research was done by using the famous Theory of Planned Behavior (TPB) model. A multivariate analysis with Structural Equation Model (SEM) was conducted, and six hypotheses were proposed. A questionnaire was used as the instrument development to gather the data needed for the purpose of this study; 155 respondents participated. The result showed that the TPB model was appropriate in revealing the Generation $\mathrm{Z}$ intention on e-wallet's usage. Statistical findings and practical perspectives were also discussed in this paper. E-wallet providers can use the result derived from this study to develops their marketing strategies.
\end{abstract}

Keywords: E-wallet; online transaction; In-store transaction; TPB; Behavior Intention.

Received: 3 October 2019

Accepted: 31 December 2020

https://doi.org/10.33736/ijbs.3171.2021

\title{
1. INTRODUCTION
}

In today's digital era, the development of financial technologies continues to grow, especially for desktop and mobile applications. The need for convenience, as well as the demand for straightforward transaction services, are the core reason for this phenomenon (Qin et al., 2017). The presence of E-wallet has made the transactions easier for people and organizations (Shin, 2009). Different countries have different governmental support for their technological development. A good example is in India, where the local government fully supports the presence of e-wallet; this enables India to transform into a cashless society (Balaji \& Balaji, 2017). E-wallet is currently among the most popular financial transaction service product. E-wallet enables its users to store receipts, coupons, business cards, bills, and making payments, substituting almost all the functions of the traditional physical wallets (Rathore, 2016). E-wallet also provides many features inexistent in other financial technologies. Some of these features enable users to order foods, book a ride, or even buy plane tickets using an e-wallet (Varsha \& Thulasiram, 2016).

The development of e-commerce and online shops increases the need for a more secure payment system, which also answered by the e-wallet system (Amoroso \& Ogawa, 2013; Chern, Kong, Lee, Lim, \& Ong, 2018). E-wallet is gaining momentum with its many offers and reward system, creating a competitive price advantage compared to another payment system available (Doan, 2014). While $70 \%$ of online shopping payments were done using debit and credit cards, e-wallet, with its flexibility, can potentially shift this number, making e-wallet as the dominant payment system in the future (Chakraborty, Lee, Bagchi-Sen, Upadhyaya, \& Rao, 2016).

Not limited to an online transaction, e-wallet is also increasingly used for the in-store transaction (Bae \& Zamrudi, 2018; Yang \& Forney, 2013). The use of in-store transactions provides benefits for customers and merchants. Merchants can reduce the cost of additional employee's salaries by 
applying the Point of Sale (PoS) system, and consumers do not have to wait too long before making a transaction (Slade, Williams, \& Dwivedi, 2013). The use of e-wallet for in-store payments is best depicted by Alipay, which uses QR codes to enable transactions between buyers and merchants (Lu, 2018).

Although there is little substantial difference between an online transaction and in-store transactions, minor contrasts were still apparent. These minor contrasts, however, can still influence marketing decisions. This study was unique in that contrasts, examining more in-depth the previous studies that tackled the topics of e-wallet for online transactions only, making in-store transactions as an additional consideration (Sharma \& Sharma, 2019; Singh \& Matsui, 2018; Sivathanu, 2019). The goal, however, is still the same: to understand different factors that influence users to use an e-wallet. The present research also focused on Generation Z, which has the most interaction with today's technologies (Turner, 2015). The decision to focus only on this generation is expected to provide a new understanding of Generation Z's underlying psychological behavior in using E-wallets in two different types of e-wallet usage: in-store and online. Indonesia is selected as a case study due to two main reasons. The first reason is how Indonesia is currently one of the big emerging markets, which is the foundation for Indonesia's financial technology future growth. The second reason is the already apparent growth trend of electronic transactions in Indonesia. A forecast shows that this year, Indonesia's e-wallet size could reach a volume of 20 billion dollars (Timones, 2019). The result of this study can provide valuable information for companies in addressing future marketing strategy decisions for these particular demographics and countries with emerging markets.

\section{LITERATURE REVIEW}

\section{$2.1 \quad$ E-Wallet}

The existence of e-wallet makes it easier for people to make transactions and access the many new services built-in inside their e-wallet applications. E-wallet supports consumer-to-online, consumer to consumer, consumer to business, and consumer to machine transactions. Currently, with the development of e-wallet, daily human transactions such as paying train ticket transactions, as well as functioning as a credit card, have been enhanced and improved (Shin, 2009). E-wallets can become a transaction tool that provides comfort and security online (Uddin \& Akhi, 2014). With the development of E-commerce as it is today, E-wallet becomes the consumer's choice to serve them in their day-to-day transactions (Hsieh, 2001; Oyelami, Adebiyi, \& Adekunle, 2020; Upadhayaya, 2012). The use of e-wallet as a transaction tool is not limited to online transactions. The flexibility of using E-wallet can be seen in its application towards Point of Sales transactions based on mobile phone payment. This transaction model makes it easy for merchants and consumers to reduce cash on hand that is relatively difficult to manage. Merchants, in general, prefer In-store transactions because, aside from its core advantages, as mentioned earlier, merchants can also offer discount coupons directly to consumers (Shin, 2009). Also, in-store transactions can reduce labor costs for merchants and the time needed to make a payment. Payment confirmation is also directly integrated into the E-Wallet application ( $\mathrm{Lu}, 2018)$. In Indonesia, the institution that governs finance and banking is Bank of Indonesia, which gives permission for ewallet providers to operate. Registered e-wallet providers existed and in 2019 there are a total of 37 registered e-wallet providers (Lingga, 2019). Since e-wallet is getting more popular, it has been 
used by many retailers and online shops as the main medium for transactions. Furthermore, a recent investigation shows that young consumers boost electronic growth especially for the merchant (J.P.Morgan, 2019).

\subsection{Generation Z's}

Generation $\mathrm{Z}$ is a generation born from the 1995-2010 range (Skinner, Sarpong, \& White, 2018). This generation has many unique characteristics, and they are literate with technology. This generation is considered the generation that is most often in contact with social media, new advanced technology, and has more knowledge in accessing the internet (Turner, 2015). However, despite being in direct contact with technological developments, this generation still has a high sense of responsibility and is considered to be individuals who adjust to traditional values (Berkup, 2014). Several pieces of research revealed that this generation tends to do online transaction more compared to other generations (DALIMUNTE et al., 2019; Dewanti \& Indrajit, 2018).

\subsection{Theory of Planned Behavior (TPB)}

The theory of planned behavior (TPB) is a development of the theory of reason action (TRA). The TPB is felt to be necessary, mainly because of the inability of the previous model to measure the behavior of individuals who are considered to have control over their will (Ajzen, 1991). This theory explains that each individual's performance is determined by his intention to behave. Different from the TRA theory, TPB also includes perceived behavioral control as an additional factor that influences individual intention. In the TPB model, attitude is considered as a feeling that can cause a sense of an individual associated with the behavior that he will do. Subjective norms represent individual perceptions of the expectations of people who are influential in their lives about a specific action. Perceived behavioral control represents the perception of the individual about the ease or difficulty of realizing a particular behavior (Liao, Chen, \& Yen, 2007). In other words, individual behavior can change depending on the situation and type of behavior (Mathieson, 1991). Figure 1 shows the theoretical framework of TPB, which is used for this research. Previously, many empirical studies have shown that individual Behavior Intention can be explained by the model, including the measurement of the use of certain technologies (Aboelmaged \& Gebba, 2013; Cheung \& To, 2017; Nasri \& Charfeddine, 2012). Therefore, the TPB model can be a theoretical basis for testing factors influencing behavioral intention to use e-wallets for instore and online transactions. Based on the previous explanation of the constructs contained in the model theory of planned behavior, then we build the research hypotheses. 
Figure 1: Theoretical Framework Theory of Planned Behavior for Online and In-store Transaction

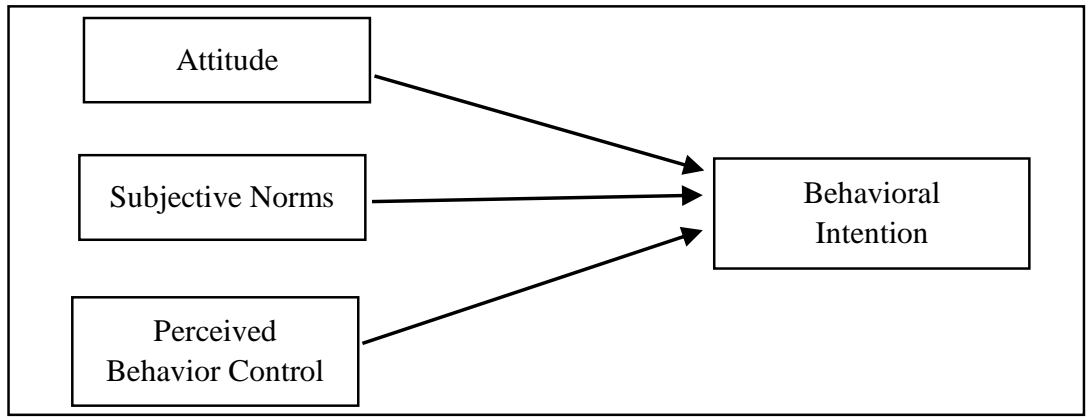

Source: (Ajzen, 1991; Persada et al., 2020)

The first hypothesis is related to consumers' attitudes towards the BI to use e-wallet for online $\left(\mathrm{H}_{1 \mathrm{a}}\right)$ and In-store transactions $\left(\mathrm{H}_{1 \mathrm{~b}}\right)$. Similar to previous research conducted by Aboelmaged and Gebba (2013), a favorable feeling can influence consumers' BI. Thus, favorable feeling (attitude) is hypothesized in this research to have a positive relationship with BI:

$H_{1 a}$ : Attitude (AT) positively affect Generation Z's Behavior Intention to use e-wallet for online transaction

$\boldsymbol{H}_{1 b}$ : Attitude (AT) positively affect Generation Z's Behavior Intention to use e-wallet for In-store transaction

The second hypothesis is related to how consumers' subjective norms toward e-wallet usage for both online $\left(\mathrm{H}_{2 \mathrm{a}}\right)$ and in-store $\left(\mathrm{H}_{2 \mathrm{~b}}\right)$ transactions affect $\mathrm{BI}$. In addition to families and close friends, social media enables access to influencers in which they could have a positive influence on ewallet's use. This relationship was also shown to be true from similar previous research (Aboelmaged \& Gebba, 2013; Nasri \& Charfeddine, 2012). Therefore:

H2a: Subjective Norms (SN positively affect Generation Z's Behavior Intention to use e-wallet for online transaction

$H_{2 b}$ : Subjective Norms (SN) positively affect Generation Z's Behavior Intention to use e-wallet for In-store transaction

The third hypothesis is related to the relationship between consumers' perceived behavior control toward e-wallet usage and their BI in both online $\left(\mathrm{H}_{3 \mathrm{a}}\right)$ and In-store $\left(\mathrm{H}_{3 \mathrm{~b}}\right)$ transactions. In the era of Generation Z, where they are accustomed to new technologies, infrastructures, and digital transactions. Perceived behavioral control becomes necessary to predicts BI in both online and instore transactions (Nasri \& Chafeddine, 2012). Thus:

$H_{3 a}$ : Perceived Behavior Control (PBC positively affect Generation Z's Behavior Intention to use $e$-wallet for online transaction

H3b: Perceived Behavior Control (PBC) positively affect Generation Z's Behavior Intention to use e-wallet for an in-store transaction. 
The final conceptual framework to summarizes the proposed hypotheses are provided in Figure 2.

Figure 2: Conceptual Framework Theory of Planned Behavior

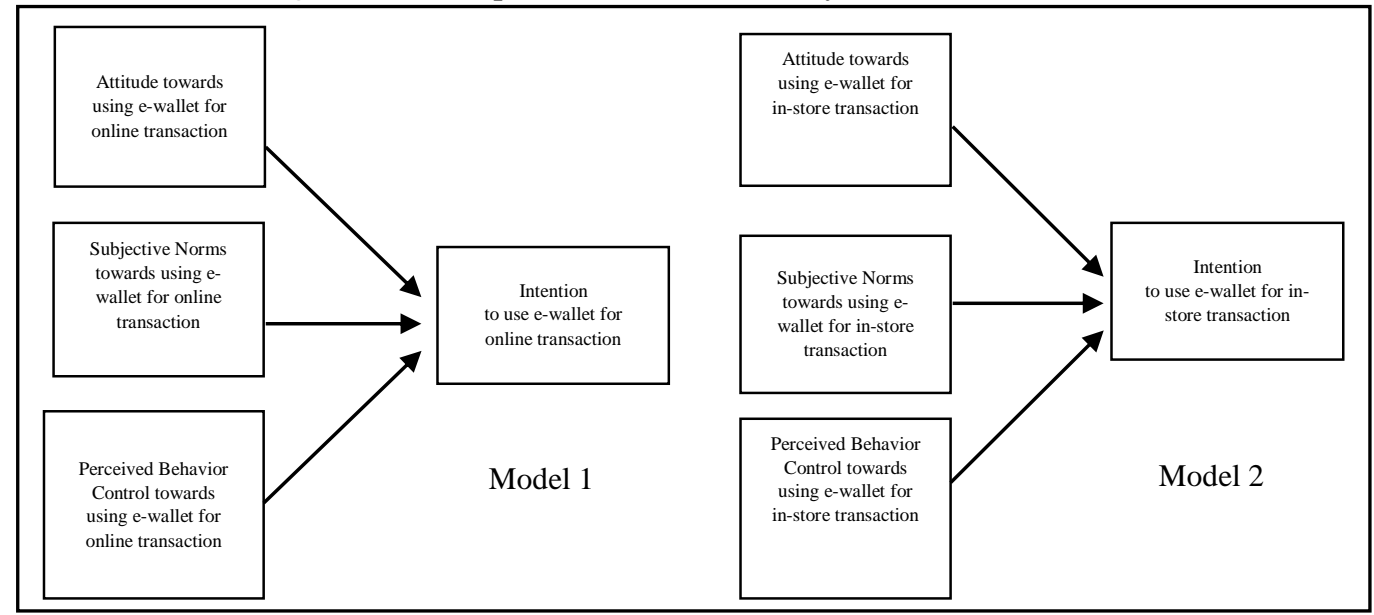

Source: Own preparation

\section{METHODOLOGY}

Following the previous explanation, this study uses TPB to measure e-wallet usage behavior. A recent report stated that Generation Z in 2019, contributes to $29 \%$ of Indonesia's population or roughly 75 million people (Deloitte Indonesia, 2019). A total of 155 Generation Z respondents filled a questionnaire developed for this study. The sample size used (155) is commonly used for an SEM model; it has also exceeded the minimum number of sample size using Yamane Taro's formula with $10 \%$ margin error, which was 100 respondents (Adam, 2020):

$$
\begin{aligned}
& n=\frac{N}{\left(1+N e^{2}\right)}=\frac{75.000 .000}{\left(1+75.000 .000 .0,10^{2}\right)}=100 \\
& \mathrm{n}=\text { Sample size } \mathrm{N}=\text { Population } \\
& \mathrm{E}=\text { Error margin }
\end{aligned}
$$

The questionnaire was distributed online using Google Forms. Before distributing the questionnaire, we gave information about the use of e-wallet to respondents to prevent information bias about using an e-wallet. This study also uses SEM analysis to evaluate structural correlations between latent variables that are constructed in our hypotheses. The reason for using SEM is because of its ability to represent the relationships that underlie the sample data in the path diagram and effectively be able to analyze latent variables relationships. We divided the questionnaire into two main parts, the first part is a questionnaire for the use of online e-wallet transactions, and the second is a questionnaire for in-store use. The questionnaire items are listed in Table 1: 
Table 1: List of Question and Variable Projected Online Transaction

\begin{tabular}{|c|c|c|}
\hline Variable & Online Transaction Question & Source \\
\hline AT 1 & Using e-wallet for online transaction is a good idea & $($ Lee, 2009) \\
\hline AT 2 & For me using e-wallet for online transaction would be a wise idea & $($ Lee, 2009) \\
\hline AT 3 & I like to use e-wallet for finishing online transaction & $($ Lee, 2009) \\
\hline SN 1 & $\begin{array}{l}\text { People important to me would think that using e-wallet for online } \\
\text { transaction would be a wise idea }\end{array}$ & (Liao et al., 2007) \\
\hline SN 2 & $\begin{array}{l}\text { People who influence my behavior think that I should use an e-wallet for } \\
\text { online transaction }\end{array}$ & (Liao et al., 2007) \\
\hline SN 3 & $\begin{array}{l}\text { People whose opinions I value prefer that I use e-wallet for online } \\
\text { transaction }\end{array}$ & (Liao et al., 2007) \\
\hline PBC 1 & I have the resources necessary to use e-wallet for online transaction & $($ Lee, 2009) \\
\hline PBC 2 & I have the knowledge necessary to use e-wallet for online transaction & $($ Lee, 2009) \\
\hline PBC 3 & I have the ability to use e-wallet for online transaction & (Lee, 2009) \\
\hline BI 1 & I will always try to use e-wallet for online transaction in my daily life & (Tan \& Lau, 2016) \\
\hline BI 2 & I plan to continue to use E-Wallet for online transaction frequently & (Tan \& Lau, 2016) \\
\hline BI 3 & I intend to continue using an E-Wallet for in-store transaction in the future & (Tan \& Lau, 2016) \\
\hline
\end{tabular}

Table 2: List of Question and Variable Projected In-store Transaction

\begin{tabular}{|c|c|c|}
\hline Variable & In-Store Transaction Question & Source \\
\hline AT 1 & Using e-wallet for in-store transaction is a good idea & $($ Lee, 2009) \\
\hline AT 2 & For me using e-wallet for in-store transaction would be a wise idea & $($ Lee, 2009) \\
\hline AT 3 & I like to use e-wallet for finishing in-store transaction & (Lee, 2009) \\
\hline SN 1 & $\begin{array}{l}\text { People who are important to me think that I should use e-Wallet for in-store } \\
\text { transaction }\end{array}$ & (Liao et al., 2007) \\
\hline SN 2 & $\begin{array}{l}\text { People who influence my behavior think that I should use an e-Wallet for in- } \\
\text { store transaction }\end{array}$ & (Liao et al., 2007) \\
\hline SN 3 & $\begin{array}{l}\text { People whose opinions I value prefer that I use e- Wallet for the in-store } \\
\text { transaction }\end{array}$ & (Liao et al., 2007) \\
\hline PBC 1 & I have the resources necessary to use e-wallet for in-store transaction & (Lee, 2009) \\
\hline $\mathrm{PBC} 2$ & I have the knowledge necessary to use e-wallet for in-store transaction & (Lee, 2009) \\
\hline PBC 3 & $\begin{array}{l}\text { e-wallet for the in-store transaction is compatible with other technologies I } \\
\text { use }\end{array}$ & $($ Lee, 2009) \\
\hline BI 1 & I intend to continue using an e-wallet for in-store transaction in the future & (Tan \& Lau, 2016) \\
\hline BI 2 & I will always try to use e-wallet for in-store transaction in my daily life & (Tan \& Lau, 2016) \\
\hline BI 3 & I plan to continue to use e-wallet for in-store transaction frequently & (Tan \& Lau, 2016) \\
\hline
\end{tabular}

The questions projected in Tables $1 \& 2$ mainly adopted from supporting literature (Lee, 2009; Tan $\&$ Lau, 2016). All questions were prepared to assess the respondents' behavior by using the 5-scale Likert. The scale depicted from 1 with strongly disagree to 5 with strongly agree (Gupta, Dogra, \& George, 2018). A test of statistical robustness was also conducted, data that have outlier tendency were removed using the approach of observations farthest from the centroid (Mahalanobis distance). Variable indicators were tested for skewness and kurtosis, all still in the -1 to +1 range, which was recommended by previous research (Gao, Mokhtarian, \& Johnston, 2008). Several other tests, such as model fit (Bhatiasevi, 2016), reliability, and convergent validity, were prepared (Shin, 2009). Furthermore, the correlation between latent variables are then able to be measured (Bacon, Sauer, \& Young, 1995; Hair, 2006; Persada, Miraja, \& Nadlifatin, 2019). 


\section{RESULTS AND DISCUSSION}

\subsection{Descriptive Statistics}

This study used a purposive sampling method for data collection ${ }^{1}$. We gathered the data from 25 different cities throughout Indonesia, with $64.3 \%$ female respondents, $34.7 \%$ male respondents, and $0.9 \%$ choosing not to answer. E-wallet usage experience is also shown in the data. It was revealed that $40.3 \%$ of our respondents have experienced using an E-wallet for less than a year, $16.4 \%$ for a year, $17 \%$ for $1-2$ years, $18.2 \%$, and only $8.1 \%$ of respondents we use E-wallet for more than four years.

\subsection{Data Analysis}

The present research utilizes the TPB model to capture the influences between variables. Several rules of thumbs were used, such as the minimum of 0.7 for Cronbach alpha as well as composite reliability (Kengatharan, 2020). Further, the minimum of 0.5 value of Average Variance Extracted (AVE) is used as a parameter. The result shows the fit values of several parameters as it can be seen in Table 2 and 3. For the sake of showing the differentiation between in-store and online usage, we have conducted analyses of these issues separately.

Table 3 : Questionnaire Reliability and Convergent Validity Measurement Result in Online Transaction

\begin{tabular}{ccccccc}
\hline \hline Factor & Item & $\begin{array}{c}\text { Factor } \\
\text { Loading }\end{array}$ & AVE & $\begin{array}{c}\text { Cronbach } \\
\text { Alpha }\end{array}$ & CR & $\mathbf{R}^{\mathbf{2}}$ \\
\hline \multirow{3}{*}{ ATT } & ATT 1 & 0,91 & 0,81 & 0,93 & 0,93 & 0,832 \\
& ATT 2 & 0,94 & & & & 0,892 \\
& ATT 3 & 0,85 & & 0,90 & 0,91 & 0,728 \\
SN & SN 1 & 0,83 & 0,77 & & & 0,694 \\
& SN 2 & 0,96 & & & & 0,913 \\
& SN 3 & 0,83 & & 0,79 & 0,79 & 0,585 \\
PBC & PBC 1 & 0,76 & 0,56 & & & 0,662 \\
& PBC 2 & 0,81 & & & 0,86 & 0,447 \\
& PBC 3 & 0,67 & & 0,90 & & 0,724 \\
BI & BI 1 & 0,87 & 0,70 & & & \\
& BI 2 & 0,85 & & & & \\
\hline \hline
\end{tabular}

Note: $\mathrm{R}^{2}$ for $\mathrm{BI}=0,402$

\footnotetext{
${ }^{1}$ This type of sampling however, has its limitations such as sampling bias and the impossibility of measuring the sampling error
} 
Table 4 : Questionnaire Reliability and Convergent Validity Measurement Result in in-store Transaction

\begin{tabular}{ccccccc}
\hline \hline Factor & Item & $\begin{array}{c}\text { Factor } \\
\text { Loading }\end{array}$ & AVE & $\begin{array}{c}\text { Cronbach } \\
\text { Alpha }\end{array}$ & CR & $\mathbf{R}^{\mathbf{2}}$ \\
\hline \multirow{3}{*}{ ATT } & ATT 1 & 0,97 & 0,91 & 0,97 & 0,97 & 0,944 \\
& ATT 2 & 0,93 & & & & 0,868 \\
& ATT 3 & 0,96 & & & & 0,924 \\
SN & SN 1 & 0,98 & 0,93 & 0,98 & 0,98 & 0,956 \\
& SN 2 & 0,97 & & & & 0,944 \\
& SN 3 & 0,95 & & & 0,86 & 0,90 \\
PBC & PBC 1 & 0,87 & 0,67 & 0,90 & & 0,727 \\
& PBC 2 & 0,77 & & & & 0,892 \\
& PBC 3 & 0,81 & & & 0,88 & 0,831 \\
BI & BI 1 & 0,82 & 0,72 & 0,96 & & 0,779 \\
& BI 2 & 0,84 & & & & \\
\hline \hline
\end{tabular}

Note: $\mathrm{R}^{2}$ for $\mathrm{BI}=0,666$

From Tables 2 and 3, We can see that the factor loading of each item representing the latent variable shows results above the recommended value of 0.7 (Yu, 2002), except for PBC 3 items on online transactions. The situation happens because the items in the questionnaire are slightly biased for respondents to answer. However, all AVE values also surpassed 0.5, showing that latent variables display convergent validity, having the ability to explain the majority of each indicators' variance. The Composite Reliability and Cronbach an of the latent variables for online transaction showing appropriate values, surpassing the required values, showing consistency in measuring a construct. The factor loading values of the in-store observed variables showing adequate numbers; all the loadings is higher than 0.7. The evidence shows that all observed variables were suitable in projecting the latent variables of the model. The situation goes the same for in-store transaction's other measures. AVE, CR, and Cronbach exhibited values higher than the recommended values.

The model fit test revealed the acceptable value for CFI and GFI, with 0.88 and 0.81 for online transactions, 0.88 , and 0.74 (moderately acceptable) for the in-store transaction (Hooper, Coughlan, \& Mullen, 2008). We have chosen CFI as an index because it is insensitive to the number of samples and less affected by the structural model complexity. GFI, on the other hand, projects the fitness of a model from the residual square of a comparison model compared with actual data. After the data and the model were deemed appropriate, hypotheses testing was able to be conducted. Further, this analysis will test the correlation estimate and significance of each correlation path. The SEM result for e-wallet usage for online transaction revealed that every TPB constructs exhibit a positive correlation with behavioral intention, with ATT showed the highest value $(\beta=0.43)$ compared to another construct. PBC showed the lowest value $(\beta=0.33)$. For the in-store transaction, positive correlations were also apparent in all constructs, with ATT showed the highest correlation $(\beta=0.69)$, and $\mathrm{PBC}$ showed the lowest correlation $(\beta=0.30)$. 
Figure 3: Model Result for Online Transaction

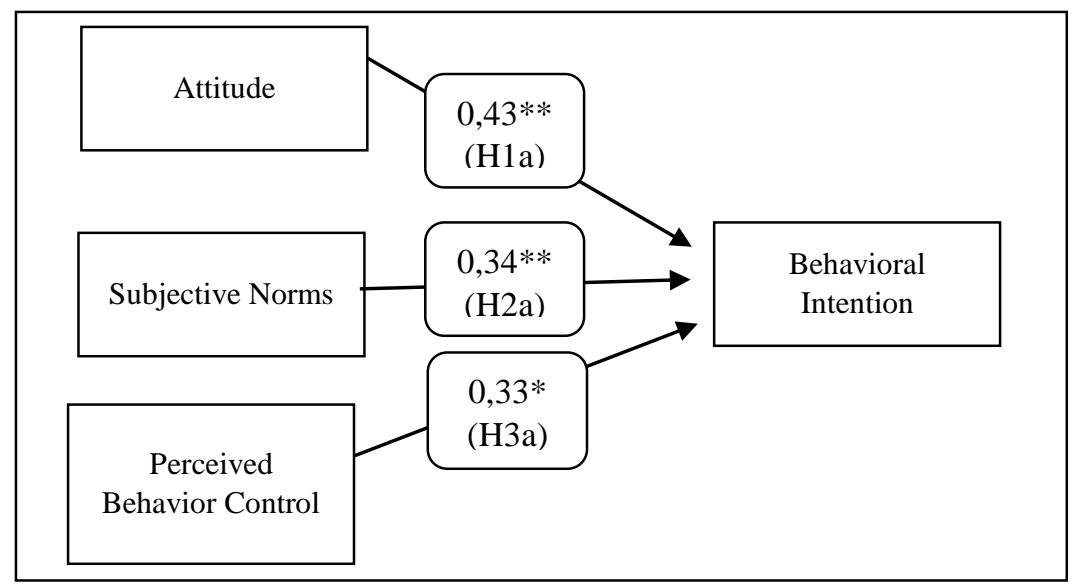

Source: Developed by the authors

Notes: $* \mathrm{P} \leq 0,05 ; * * \mathrm{P} \leq 0,01$

Figure 4: Model Result for In-store Transaction

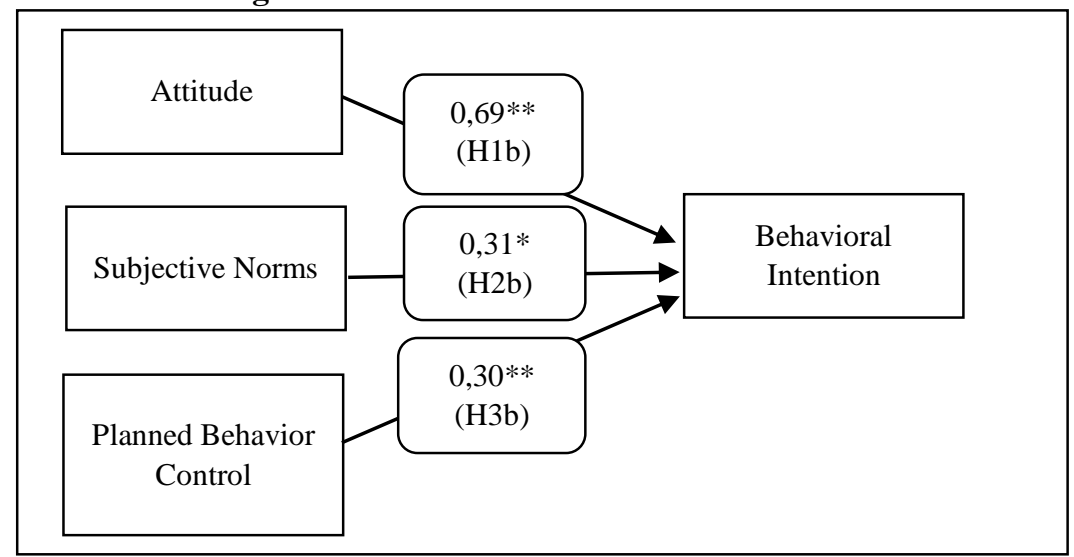

Source: Developed by the authors

Next, we confirmed our hypothesis by doing significance testing for each hypothesis on the model constructs. For online transaction, ATT $\rightarrow \mathrm{BI}$ and $\mathrm{SN} \rightarrow \mathrm{BI}$ showed a significant result. Likewise, with ATT $\rightarrow$ BI, SN $\rightarrow$ BI in-store transactions showed significant results. While the magnitude of the coefficient of determination for online transactions is indicated by Squared Multiple Regression $\left(\mathrm{R}^{2}=0.42\right)$ which means that the variability of Behavioral Intention (BI) can be explained by the variability of Attitude (ATT), Subjective Norms (SN), and Perceived Behavioral Control (PBC) by $40.2 \%$ while $59.8 \%$ are other variables not examined under the present conceptual framework. So it can be concluded that the model is good. Likewise, with in-store transactions that show numbers $\left(\mathrm{R}^{2}=0.666\right)$ or are able to represent the research model of $66.6 \%$ and the model is still acceptable. 
Table 5 : Significance of the correlation results

\begin{tabular}{ccc}
\hline Constructs & $\begin{array}{c}\text { Coefficient Correlation } \\
\text { (Online) }\end{array}$ & $\begin{array}{c}\text { Coefficient Correlation } \\
\text { (In-store) }\end{array}$ \\
\hline $\mathrm{ATT} \rightarrow \mathrm{BI}$ & $0,005^{* *}$ & $0,002^{* *}$ \\
$\mathrm{SN} \rightarrow \mathrm{BI}$ & $0,008^{* *}$ & $0,004^{* *}$ \\
$\mathrm{PBC} \rightarrow \mathrm{BI}$ & $0,018^{*}$ & $0,031^{*}$ \\
\hline \hline
\end{tabular}

Source: Author's Calculations

Notes: $* \mathrm{P} \leq 0,05 ; * * \mathrm{P} \leq 0,01$

\section{CONCLUSION}

The present research expands our knowledge in the particular topic of technology adoption, especially in the subject of financial technology. The present research investigates two means of using an e-wallet, online, and in-store. This research found that there was little difference between e-wallet's online and in-store transaction. If previous studies only measure the use of e-wallets through online transaction types, it is very lacking for the e-wallet service industry to gain insight into future service strategies. This research found that the intention of Generation $\mathrm{Z}$ to use e-wallet was illustrated from the results of the ATT hypothesis, which is a determining factor that using ewallet as a transaction can facilitate them and feel it is a good idea. Besides, Generation $\mathrm{Z}$ feels that the people around them are very influential in using e-wallets that are shown in the SN hypothesis. Generation $\mathrm{Z}$ feels that the infrastructure that determines them to use e-wallets is not very significant, because they think that some facilities such as the internet and mobile phones are not the main obstacle, but the discount services offered by the company are their reasons for using e-wallets. Therefore, companies need to be able to design strategies and recognize the behavior of Generation $\mathrm{Z}$ consumers in using E-wallets for online and in-store transactions.

\section{ACKNOWLEDGEMENT}

The authors want to thank all those who were involved in this research. All information and advice given to researchers will be input for the future.

\section{REFERENCES}

Aboelmaged, M., \& Gebba, T. R. (2013). Mobile banking adoption: an examination of technology acceptance model and theory of planned behavior. International Journal of Business Research and Development, 2(1).

Adam, A. M. (2020). Sample size determination in survey research. Journal of Scientific Research and Reports, 90-97.

Ajzen, I. (1991). The theory of planned behavior. Organizational behavior and human decision processes, 50(2), 179-211.

Amoroso, D. L., \& Ogawa, M. (2013). Comparing mobile and Internet adoption factors of loyalty and satisfaction with online shopping consumers. International Journal of E-Business Research (IJEBR), 9(2), 24-45. 
Bacon, D. R., Sauer, P. L., \& Young, M. (1995). Composite reliability in structural equations modeling. Educational and psychological measurement, 55(3), 394-406.

Bae, I.-H., \& Zamrudi, M. F. Y. (2018). Challenge of Social Media Marketing \& Effective Strategies to Engage More Customers: Selected Retailer Case Study. International Journal of Business \& Society, 19(3).

Balaji, K., \& Balaji, K. (2017). A study on demonetization and its impact on cashless transactions. International Journal of Advanced Scientific Research \& Development, 4(3), 58-64.

Berkup, S. B. (2014). Working with generations X and Y in generation Z period: Management of different generations in business life. Mediterranean Journal of Social Sciences, 5(19), 218.

Bhatiasevi, V. (2016). An extended UTAUT model to explain the adoption of mobile banking. Information Development, 32(4), 799-814.

Chakraborty, R., Lee, J., Bagchi-Sen, S., Upadhyaya, S., \& Rao, H. R. (2016). Online shopping intention in the context of data breach in online retail stores: An examination of older and younger adults. Decision Support Systems, 83, 47-56.

Chern, Y. X., Kong, S. Y., Lee, V. A., Lim, S. Y., \& Ong, C. P. (2018). Moving into cashless society: factors affecting adoption of e-wallet. UTAR.

Cheung, M. F., \& To, W.-M. (2017). The influence of the propensity to trust on mobile users' attitudes toward in-app advertisements: An extension of the theory of planned behavior. Computers in Human Behavior, 76, 102-111.

Dalimunte, I., Miraja, B. A., Persada, S. F., Prasetyo, Y. T., Belgiawan, P. F., \& Redi, A. P. (2019). Comparing Generation Z's Behavior Intention in Using Digital Wallet for Online and Instore Transaction: A Unified Theory of Acceptance and Use of Technology 2 Approach. Editorial Board, 660.

Deloitte Indonesia. (2019). Millennials in Industry 4.0: A Gift or a Threat to Indonesian Human Resources? Retrieved from https://www2.deloitte.com/content/dam/Deloitte/id/ Documents/about-deloitte/id-about-dip-edition-1-chapter-2-en-sep2019.pdf

Dewanti, P., \& Indrajit, R. E. (2018). The effect of XYZ generation characteristics to e-commerce C-to-C: A review. IKRA-ITH INFORMATIKA: Jurnal Komputer dan Informatika, 2(2), $56-60$.

Doan, N. (2014). Consumer adoption in mobile wallet: a study of consumers in Finland.

Gao, S., Mokhtarian, P. L., \& Johnston, R. A. (2008). Nonnormality of data in structural equation models. Transportation Research Record, 2082(1), 116-124.

Gupta, A., Dogra, N., \& George, B. (2018). What determines tourist adoption of smartphone apps? An analysis based on the UTAUT-2 framework. Journal of Hospitality and Tourism Technology, 9(1), 50-64.

Hair, J. F. (2006). Multivariate data analysis: Pearson Education India.

Hooper, D., Coughlan, J., \& Mullen, M. (2008). Structural equation modelling: Guidelines for determining model fit. Articles, 2.

Hsieh, C. t. (2001). E-commerce payment systems: critical issues and management strategies. Human Systems Management, 20(2), 131-138.

J.P.Morgan. (2019). E-commerce Payments Trends: Indonesia. Retrieved from https://www. jpmorgan.com/merchant-services/insights/reports/indonesia

Kengatharan, N. (2020). Home Is Where the Heart Is: Factors Determining Family Demand and Its Implications for Hrm Practices. International Journal of Business and Society, 21(1), 153-167. 
Lee, C. M. (2009). Factors influencing the adoption of internet banking: An integration of TAM and TPB with perceived risk and perceived benefit. Electronic Commerce research and applications, 130-141.

Liao, C., Chen, J.-L., \& Yen, D. C. (2007). Theory of planning behavior (TPB) and customer satisfaction in the continued use of e-service: An integrated model. Computers in Human Behavior, 23(6), 2804-2822.

Lingga, M. A. (2019). Ada 37 Uang Elektronik yang Ada di Indonesia, Apa Saja? Retrieved from https://money.kompas.com/read/2019/03/23/063000326/ada-37-uang-elektronik-yangada-di-indonesia-apa-saja

Lu, L. (2018). Decoding Alipay: mobile payments, a cashless society and regulatory challenges. Butterworths Journal of International Banking and Financial Law, 40-43.

Mathieson, K. (1991). Predicting user intentions: comparing the technology acceptance model with the theory of planned behavior. Information systems research, 2(3), 173-191.

Nasri, W., \& Charfeddine, L. (2012). Factors affecting the adoption of Internet banking in Tunisia: An integration theory of acceptance model and theory of planned behavior. The Journal of High Technology Management Research, 23(1), 1-14.

Oyelami, L. O., Adebiyi, S. O., \& Adekunle, B. S. (2020). Electronic payment adoption and consumers' spending growth: empirical evidence from Nigeria. Future Business Journal, $6(1), 1-14$.

Persada, S. F., Ivanovski, J., Miraja, B. A., Nadlifatin, R., Mufidah, I., Chin, J., \& Redi, A. A. N. P. (2020). Investigating Generation Z'Intention to Use Learners' Generated Content for Learning Activity: A Theory of Planned Behavior Approach. International Journal of Emerging Technologies in Learning (iJET), 15(04), 179-194.

Persada, S. F., Miraja, B. A., \& Nadlifatin, R. (2019). Understanding the Generation Z Behavior on D-Learning: A Unified Theory of Acceptance and Use of Technology (UTAUT) Approach. International Journal of Emerging Technologies in Learning, 14(5).

Qin, Z., Sun, J., Wahaballa, A., Zheng, W., Xiong, H., \& Qin, Z. (2017). A secure and privacypreserving mobile wallet with outsourced verification in cloud computing. Computer Standards \& Interfaces, 54, 55-60.

Rathore, H. S. (2016). Adoption of digital wallet by consumers. BVIMSR's Journal of Management Research, 8(1), 69.

Sharma, M., \& Sharma, S. K. (2019). Theoretical Framework for Digital Payments in Rural India: Integrating UTAUT and Empowerment Theory. Paper presented at the International Working Conference on Transfer and Diffusion of IT.

Shin, D.-H. (2009). Towards an understanding of the consumer acceptance of mobile wallet. Computers in Human Behavior, 25(6), 1343-1354.

Singh, M., \& Matsui, Y. (2018). How long tail and trust affect online shopping behavior: An extension to UTAUT2 framework. Pacific Asia Journal of the Association for Information Systems, 9(4).

Sivathanu, B. (2019). Adoption of digital payment systems in the era of demonetization in India: an empirical study. Journal of Science and Technology Policy Management, 10(1), 143171.

Skinner, H., Sarpong, D., \& White, G. R. (2018). Meeting the needs of the Millennials and Generation Z: gamification in tourism through geocaching. Journal of Tourism Futures.

Slade, E. L., Williams, M. D., \& Dwivedi, Y. (2013). Extending UTAUT2 To Explore Consumer Adoption Of Mobile Payments. UKAIS, 36. 
Tan, E., \& Lau, J. L. (2016). Behavioural intention to adopt mobile banking among the millennial generation. Young Consumers.

Timones, L. (2019). Total e-wallet size in Indonesia likely to hit $\$ 15$ billion by 2020. The Asian Banker. Retrieved from http://www.theasianbanker.com/updates-and-articles/indonesiamobile-payments-still-closely-tied-to-mobile-top-ups-and-online-purchases

Turner, A. (2015). Generation Z: Technology and social interest. The Journal of Individual Psychology, 71(2), 103-113.

Uddin, M. S., \& Akhi, A. Y. (2014). E-wallet system for Bangladesh an electronic payment system. International Journal of Modeling and Optimization, 4(3), 216.

Upadhayaya, A. (2012). Electronic Commerce and E-wallet. International Journal of Recent Research and Review, 1, 37-41.

Varsha, R., \& Thulasiram, M. (2016). Acceptance of e-wallet services: A study of consumer behavior. International Journal of Innovative Research in Management Studies, 1(4), 2455-7188.

Yang, K., \& Forney, J. C. (2013). The moderating role of consumer technology anxiety in mobile shopping adoption: differential effects of facilitating conditions and social influences. Journal of Electronic Commerce Research, 14(4), 334.

Yu, C.-Y. (2002). Evaluating cutoff criteria of model fit indices for latent variable models with binary and continuous outcomes (Vol. 30): University of California, Los Angeles Los Angeles. 